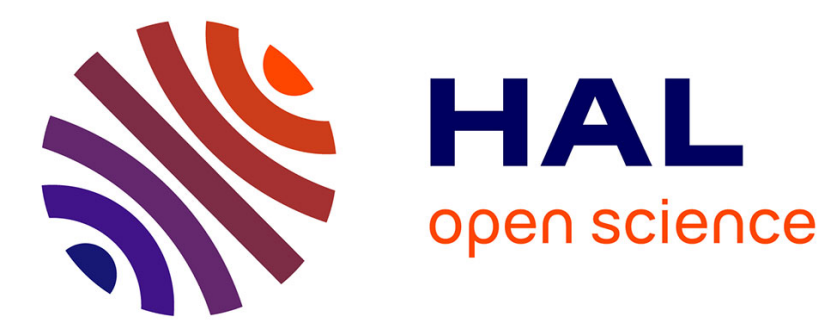

\title{
The Raman spectrum of magnesium fluoride
}

\author{
R.S. Krishnan, R.S. Katiyar
}

\section{To cite this version:}

R.S. Krishnan, R.S. Katiyar. The Raman spectrum of magnesium fluoride. Journal de Physique, 1965, 26 (11), pp.627-629. 10.1051/jphys:019650026011062700 . jpa-00206049

\section{HAL Id: jpa-00206049 https://hal.science/jpa-00206049}

Submitted on 1 Jan 1965

HAL is a multi-disciplinary open access archive for the deposit and dissemination of scientific research documents, whether they are published or not. The documents may come from teaching and research institutions in France or abroad, or from public or private research centers.
L'archive ouverte pluridisciplinaire HAL, est destinée au dépôt et à la diffusion de documents scientifiques de niveau recherche, publiés ou non, émanant des établissements d'enseignement et de recherche français ou étrangers, des laboratoires publics ou privés. 


\title{
THE RAMAN SPECTRUM OF MAGNESIUM FLUORIDE
}

\author{
By R. S. KRISHNAN and R. S. KATIYAR, \\ Department of Physics, Indian Institute of Science, Bengalore 12.
}

\begin{abstract}
Résumé. - On a étudié le spectre Raman d'un monocristal de $\mathrm{MgF}_{2}$, excité par la radiation de résonance du mercure. Les raies Raman observées correspondent à des déplacements de fréquence $73,90,154,165,295,405,415,560,2472$ et $2535 \mathrm{~cm}^{-1}$. Ce spectre a été analysé à partir des données infrarouges de Barker, et les constantes de force ont été calculées. Les valeurs de ces constantes suggèrent un caractère fortement moléculaire de la structure de $\mathrm{MgF}_{2}$.
\end{abstract}

Abstract. - The Raman spectrum of a single crystal of $\mathrm{MgF}_{2}$ has been investigated using the resonance radiation of mercury as exciter. The observed Raman lines are of frequency shifts 73 , $90,154,165,295,405,415,560,2472$ and $2535 \mathrm{~cm}^{-1}$. An analysis of the vibration spectrum has been made taking into account the infrared data of Barker, and the force constants have been calculated. The force constants suggest that the structure of $\mathrm{MgF}_{2}$ has considerable molecular character.

Magnesium fluoride, which occurs in nature as the mineral sellaite, crystallizes with rutile structure. Excellent quality single crystals are made in small scale production by "Optovac" and in view of its useful physical properties and the increasing application it finds in infrared and in masers, a knowledge of its vibration spectrum is of importance. Although the polarized infrared reflection spectrum of oriented samples of $\mathrm{MgF}_{2}$ has been studied by A. S. Barker [1], the Raman spectrum of $\mathrm{MgF}_{2}$ is not known hitherto. Since the structure of $\mathrm{MgF}_{2}$ is such that only four of the eleven possible vibrations are infrared active, a study of its Raman spectrum is essential for an understanding of its vibrational spectrum.

The single crystal of $\mathrm{MgF}_{2}$ used in the present investigation was a gift from the Optovac Inc. Mass. and was about $3 \mathrm{~cm}$ long and $1 \mathrm{~cm}$ in dia- meter. It was ground and polished by the standard methods. As the crystal was transparent to the ultraviolet, the resonance radiation of mercury $\lambda 2537$ was employed for exciting its Raman spectrum. The spectrum was recorded with a Hilger medium quartz spectrograph having a linear dispersion of about $140 \mathrm{~cm}^{-1}$ per $\mathrm{mm}$ in this spectral region. The light was incident perpendicular to the axis of the cylindrical specimen and the scattered light was along the axis which was roughly the optic axis of the crystal also. Using a slit width of $0.02 \mathrm{~mm}$ and Zenith Astronomical plate, exposures of the order of 48 hours had to be given to obtain an intense picture. In all 10 Raman lines were observed and their frequency shifts have been given in Table 1, while the spectrum with its microphotometer record has been reproduced in figure 1.

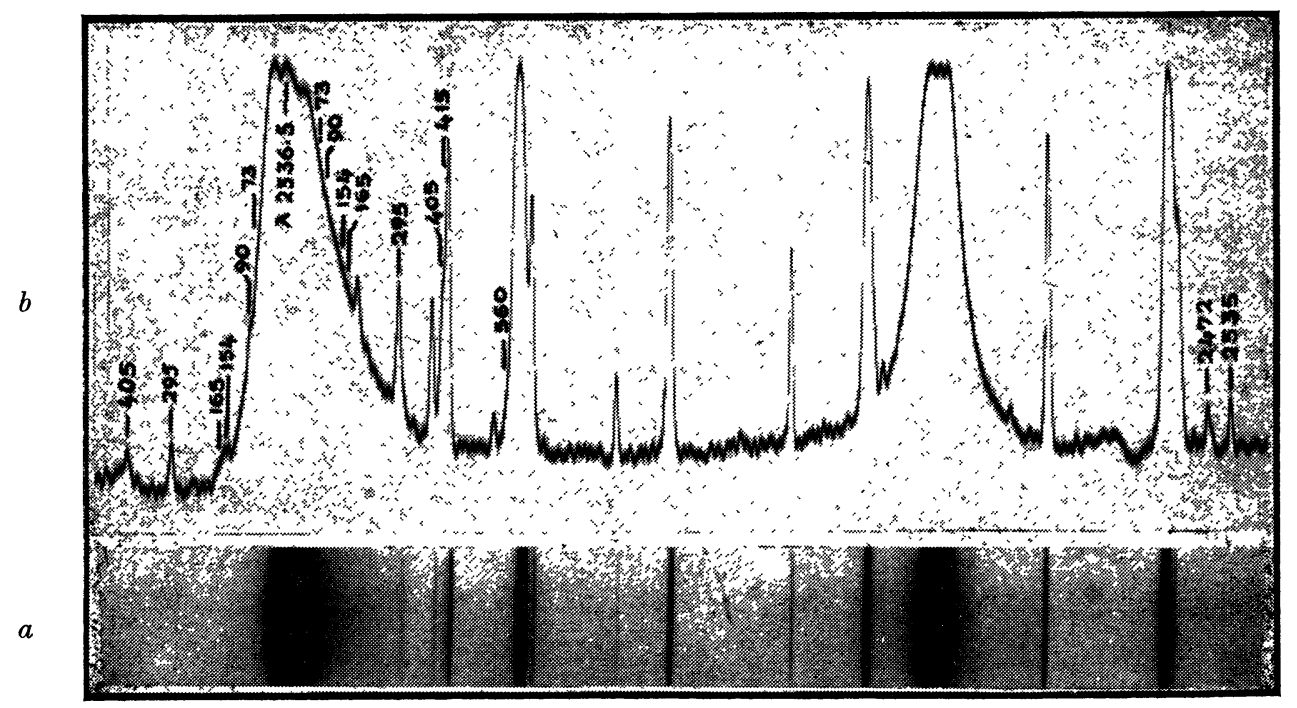

FIG. 1. - (a) Raman spectrum of magnesium fluoride $\left(\mathrm{MgF}_{2}\right)$ taken with a medium Quartz spectrograph. (b) Its microphotometer record. 
TABLE I

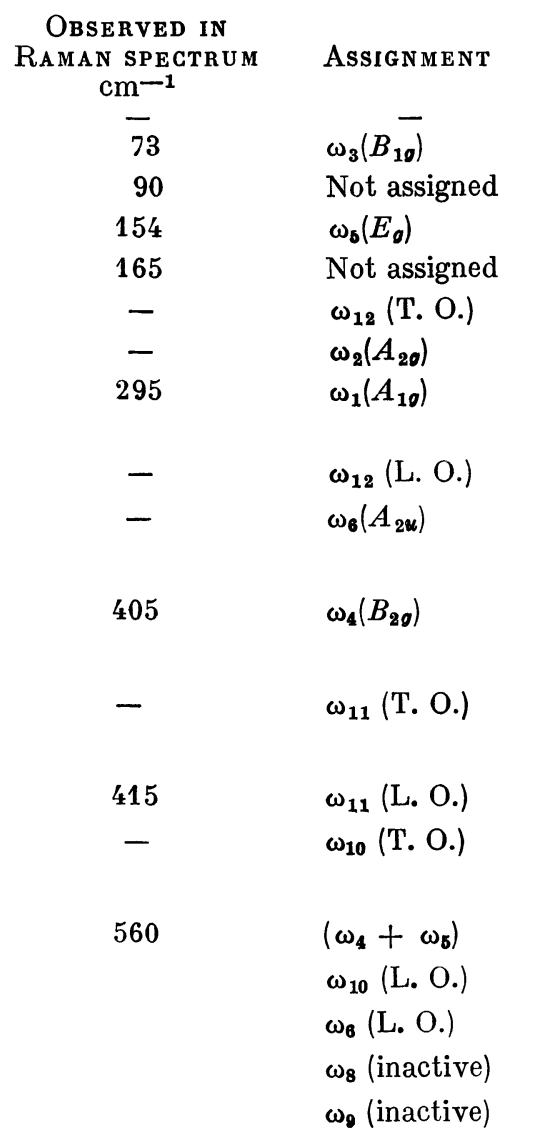

$\begin{array}{cc}\begin{array}{c}\text { INFRARED } \\ \text { FREQUENCIES } \\ \text { (BARKER Cm }\end{array}{ }^{-1} \text { ) } & \begin{array}{c}\text { Calculated } \\ \text { Cm-1 }^{-1}\end{array} \\ - & - \\ - & - \\ - & 161 \\ - & - \\ 247 & 205 \\ - & 287 \\ - & 295 \\ & \text { (assumed) } \\ 303 & - \\ 399 & 399 \\ & \text { (assumed) } \\ - & 405 \\ & \text { (assumed) } \\ 410 & 400 \\ & \text { (assumed) } \\ 415 & - \\ 450 & 460 \\ & \text { (assumed) } \\ 556 & - \\ 617 & - \\ 625 & - \\ & 428 \\ & 166\end{array}$

Magnesium fluoride has the same tetragonal structure as rutile and belongs to the space group $P 4_{2} / \mathrm{mnm}$ and the point group symmetry is $D_{4 h}$. There are 2 molecules in the unit cell and the unit cell dimensions are $a=4.621 \AA$ and $c=3.05 \AA[2]$. The unit cell contains $2-\mathrm{Mg}$ atoms in the position $(0,0,0)$ and $\left(\frac{1}{2} \cdot \frac{1}{2}, \frac{1}{2}\right)$ and 4-F atoms in the positions $\left(\frac{1}{2}-u, \frac{1}{2}+u, \frac{1}{2}\right)$; $\left(\frac{1}{2}+u, \frac{1}{2}-u, \frac{1}{2}\right) ;(u, u, 0)$ and $(\bar{u}, \bar{u}, 0)$ with $u=0.31$. The structure may easily be visualised and is shown in figure $2 a$ and the projection in figure $2 b$.

The number of vibrational frequencies under the different symmetry types of $D_{4 h}$ may be written by standard group theoretical methods as has been done by Narayanan P. S. for rutile [3]. The 15 possible modes of vibration are distributed as $1 A_{1 \sigma}+1 A_{2 g}+1 A_{2 u}+1 B_{1 \sigma}$ $+2 B_{1 u}+1 B_{2 s}+1 E_{g}+3 E_{u}$. The two modes of type $B_{1 u}$ and one of type $A_{2}$ o are inactive in both Raman and infrared spectra.

Thus 4 distinct frequencies are allowed in Raman effect and 4 distinct frequencies in infrared absorption. However on account of Coulomb interaction the longitudinal and transverse optic vibration frequencies have different values in accordance with the Lyddane-Sachs-Teller relation [1]. While Barker has identified the eight infrared mode frequencies with the help of their polarization characteristic and theoretical dispersion relation, a calculation of the vibration spectrum of $\mathrm{MgF}_{2}$ as has been done by F. Matossi [4], [5] for rutile will make it possible for us to give a definite assignment of the observed Raman lines. The general frequency formulas for the different species have been given in [4] and a numerical calculation for $\mathrm{MgF}_{2}$ was made employing a harmonic force system considering bond stretching forces between

$\mathrm{Mg}-\mathrm{F}$ (horizontal e.g. 5-1 in figure) force constant $k_{1}$,

$\mathrm{Mg}-\mathrm{F}$ (oblique e.g. $1-6$ ) force constant $k_{2}$, $\mathrm{F}$ - F (horizontal e.g. $1-7$ ) force constant $k^{\prime}$, $F-F$ (oblique e.g. $1-4$ ) force constant $k^{\prime \prime}$, and bond bending forces at

$\mathrm{Mg}$ (e.g. angle 4-6-3 in the horizontal plane) force constant $d_{1}$, 
(a)

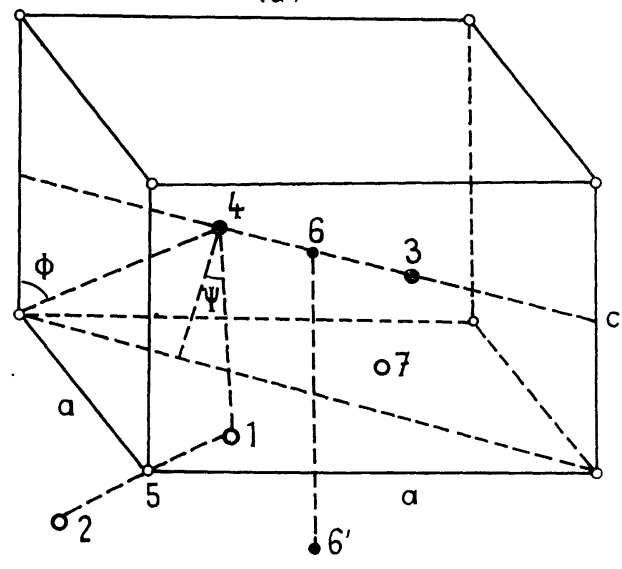

- Fluorine

- Magnesium

Shaded circles are the atoms

at level $C / 2$ above the basal plane

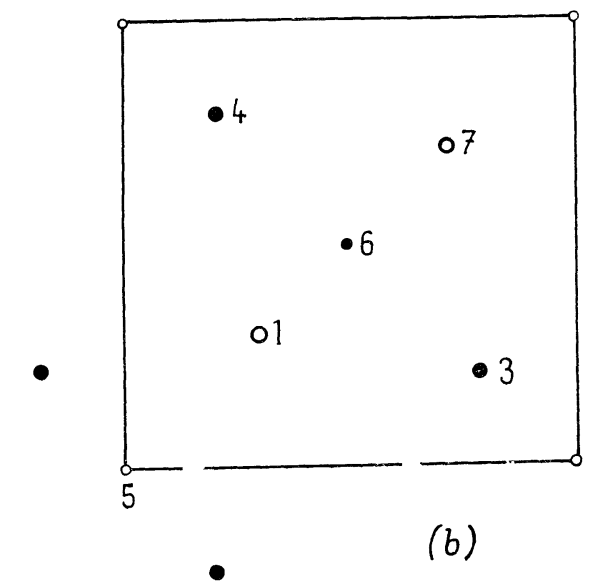

02

Projuction on (001) plane

FIg. 2.
$\mathrm{Mg}$ (e.g. angle 4-6-3 in the vertical plane) force constant $d_{2}$,

F (e.g. oblique angle 6-1-6 $6^{\prime}$ ) force constant $d_{3}$.

In the present calculation the frequencies 399 , $400,460,405$ and $295 \mathrm{~cm}^{-1}$ were assumed and also their assignment as indicated in Table I. A preliminary check showed that as in rutile, it is possible to get a satisfactory agreement between the calculated and observed frequencies even if $k_{2}=0$ and $d_{3}=0$ showing thereby that from the vibrational point of view the $\mathrm{MgF}_{2}$ structure is molecular in character. The two possible sets of force constants are

$$
\left.\begin{array}{l}
k_{1}=0.709 \\
k^{\prime}=0.108 \\
k^{\prime \prime}=0.123 \\
d_{1}=0.348 \\
d_{2}=0.359
\end{array}\right\} \times 10^{5} \text { dynes } / \mathrm{cm}
$$

and

$$
\left.\begin{array}{l}
k_{1}=0.717 \\
k^{\prime}=0.104 \\
k^{\prime \prime}=0.123 \\
d_{1}=0.348 \\
d_{2}=0.359
\end{array}\right\} \times 10^{5} \text { dynes } / \mathrm{cm}
$$

A comparison of the calculated and observed Raman shifts in Table I shows that the agreement is reasonable. In the first approximation one would expect the g-u selection to be valid even is the infrared modes split under Coulomb interaction. However the observed line at $415 \mathrm{~cm}^{-1}$ if identical with the $\omega_{11}(L O)$ reported by Barker and is therefore assigned to this mode. No definite assignment is made now to the Raman lines at 2472 and $2535 \mathrm{~cm}^{-1}$ but they probably owe their origin to a localized mode due to some impurity. Further work on this is in progress.

Our sincere thanks are due to Mr. Robert Meller of Optovac for presenting us the specimen of $\mathrm{MgF}_{2}$ used in this study.

\section{REFERENGES}

[1] Barker (A. S.), Plıys. Rev., 1964, 136, 1290.

[2] Duncanson (A.) and Stevenson (R. W. H.), Proc. Phys. Soc., London, 1958, 72, 1001.
[3] Narayanan (P. S.), Proc. Ind. Acad. Sci., 1950, 32 A, 279.

[4] Matossi (F.), J. Chem. Phys., 1951, 19, 1543,

[5] Matossi (F.), Z. Physik, 1963, 173, 1. 